\title{
LINKING CROP WATER PRODUCTIVITY TO SOIL PHYSICAL, CHEMICAL AND MICROBIAL PROPERTIES
}

\author{
Di WU', Allan A. ANDALES², Hui YANG', Qing SUN', Shichao CHEN', Xiuwei GUO', \\ Donghao LI', Taisheng DU $(\triangle)^{1}$
}

1 Center for Agricultural Water Research in China, China Agricultural University, Beijing 100083, China.

2 Department of Soil and Crop Sciences, Colorado State University, Colorado 80526, USA.

\section{KEYWORDS}

crop water productivity, crop yield, soil chemical properties, soil microbial properties, soil physical properties, water consumption

\section{HIGHLIGHTS}

- The linkage between crop water productivity and soil properties were summarized.

- Knowledge of soil microbial effects on crop water productivity is still limited.

- Knowledge of interactions of soil factors on crop water productivity is still limited.

Received March 5, 2020;

Accepted May 1, 2020.

Correspondence: dutaisheng@cau.edu.cn

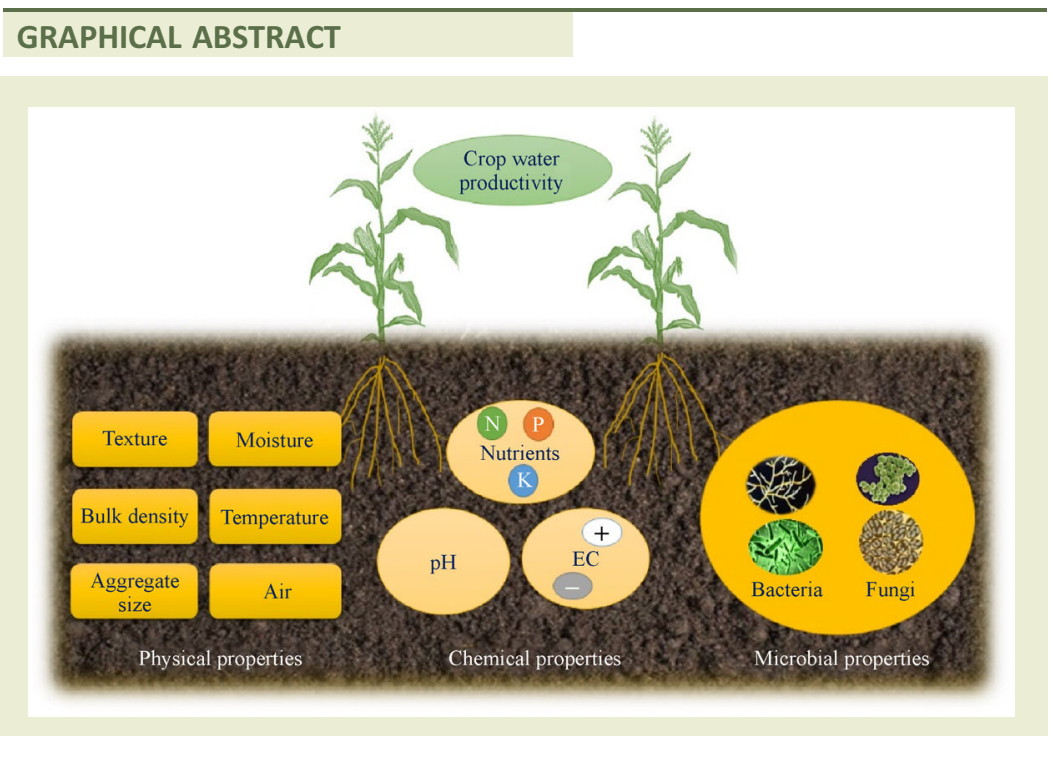

ABSTRACT

Agriculture uses a large proportion of global and regional water resources. Due to the rapid increase of population in the world, the increasing competition for water resources has led to an urgent need in increasing crop water productivity for agricultural sustainability. As the medium for crop growth, soils and their properties are important in affecting crop water productivity. This review examines the effects of soil physical, chemical, and microbial properties on crop water productivity and the quantitative relationships between them. A comprehensive view of these relationships may provide important insights for soil and water management in arable land for agriculture in the future.

\section{INTRODUCTION}

The annual total water consumption comprising agricultural water, industrial water and domestic water has increased from $580 \mathrm{~km}^{3}$ in 1900 to $3900 \mathrm{~km}^{3}$ in 2010 worldwide ${ }^{[1]}$. It resulted in a substantial decline in the availability of water resources globally ${ }^{[1]}$. The water consumed by agriculture represents nearly $70 \%$ of the total freshwater consumption, of which irrigation accounts for the largest share ${ }^{[1]}$. Crop water productivity represents the crop yield per unit of water 
consumed $^{[2]}$. A larger crop water productivity indicates higher agricultural production with less water. Therefore, a comprehensive understanding of crop water productivity is imperative to develop a more sustainable agriculture with higher productivity, lower water consumption and healthier environment $^{[3]}$.

The understanding of crop water productivity has continued to change over the past 60 years. Initially, a linear relationship was found between dry matter production and transpiration ${ }^{[4]}$. Crop water productivity was initially defined as the ratio of average dry matter or marketable crop weight produced per unit area and evapotranspiration required ${ }^{[5]}$. Subsequently, with an expanding population and scarce water resources, greater attention has been given to the economic output of agricultural water resources. Against this background the International Water Management Institute proposed a definition of crop water productivity $^{[6]}$ that refers to crop yield generated per unit of water consumption. Crop water productivity can be measured and calculated at three scales, i.e. the leaf, the field and the ecosystem. Each of these scales has a different definition of water productivity commonly used at that scale. Water productivity at the leaf scale refers to the ratio between net photosynthetic rate and transpiration rate. At the field scale it is defined as the total crop biomass or yield produced per unit of water during the crop growing period. At the ecosystem scale, water productivity is calculated as the ratio between net ecosystem productivity and ecosystem evapotranspiration ${ }^{[2]}$.

Based on this understanding of crop water productivity great efforts have been made to further explore the effects of various factors on crop water productivity, to provide deeper insights into the mechanisms regulating crop water productivity, and also to provide better capability to predict crop water productivity. Studies reveal that numerous factors can affect crop water productivity, including climate ${ }^{[7]}$, crop species and cultivar $^{[8]}$, field management ${ }^{[3]}$ and soil properties ${ }^{[7]}$.

Our group has analyzed the contributions made by all these factors at different scales using the partial least square regression method in Hexi Corridor, Gansu province, north-west China. At the field scale the silt, soil water, and soil available nitrogen rates were positively correlated with yield. In contrast, the sand content and soil electrical conductivity were negatively correlated with yield ${ }^{[9]}$. The contribution rate of soil properties to the irrigation water productivity was about $32.6 \%$ at the irrigation district scale, and it increased to $63.4 \%$ at the watershed scale. This indicates the important influence of soil properties on crop yield and water productivity ${ }^{[10]}$.
The effects of soil properties on crop water productivity can be more complex than those of climate, crop species and cultivars, and field management. There are numerous abiotic properties in soils, comprising physical properties (e.g., texture, bulk density, moisture content and temperature) and chemical properties (e.g., soil organic carbon content, soil nitrogen content, $\mathrm{pH}$ and electrical conductivity). Soils also possess the largest biodiversity of biotic communities in the biosphere, with bacteria, fungi (including mycorrhizas), actinomycetes and nematodes ${ }^{[11]}$. These physical, chemical and biotic properties interact tightly with each other and have interactive effects on the carbon and water cycles in agricultural ecosystems ${ }^{[12]}$.

Additionally, climate and field management can influence crop water productivity by affecting various soil properties. Collectively, the great number of properties in soils and the close interaction among these properties as well as with climate and field management limit us from having a comprehensive insight into linkages between crop water productivity and soil properties. It is therefore essential to gain a comprehensive understanding of the effects of soil properties on crop water productivity by reviewing previous associated studies. Here, we aim to explore three main scientific issues: (1) the effects of soil physical properties on crop water productivity, (2) how soil chemical properties affect crop water productivity, and (3) the effects of soil microbial properties on crop water productivity.

\section{LINKAGE BETWEEN CROP WATER PRODUCTIVITY AND SOIL PHYSICAL PROPERTIES}

\subsection{Effects of soil texture on crop water productivity}

Soil texture refers to the proportions of different-sized particles in a soil. According to the US Department of Agriculture Classification System, soil textural classes comprise coarse sandy soils (sands and loamy sands), moderately coarse loamy soils (sandy loams and fine sandy loams), medium loamy soils (very fine sandy loams, loams, silt loams and silts), moderately fine loamy soils (sandy clay loams, silty clay loams and clay loams) and fine clayey soils (sandy clays, silty clays and clays) ${ }^{[12]}$. Concerning the effects of soil physical properties on crop water productivity, soil texture is a primary factor that influences soil water retention and infiltration capacity, crop root distribution and uptake of water and nutrients ${ }^{[13]}$.

Generally, loamy soils are conducive to a higher crop water 
productivity. This has been found for various kinds of crops including grain crops and industrial crops in different studies. Comparative field experiments have produced significantly higher crop water productivity in maize $e^{[14]}$, soybean ${ }^{[15]}$, wheat and other crops ${ }^{[16]}$ when they were grown in loamy soils. Another approach to evaluate the effects of soil texture on crop water productivity is model simulation. Using a range of crop models (e.g., the CropSyst model, the STICS model and the CERES-Wheat crop-growth simulation model), increased crop water productivity in loamy soils (especially silt loamy soils) has also been found in diverse crops such as maize ${ }^{[17]}$ and wheat ${ }^{[18]}$. The reason why loamy soils generally support a higher crop water productivity is mainly associated with the following two aspects. One is that loamy soils generally have more available water and allow easier soil water movement ${ }^{[19]}$. Another aspect is that loamy soils can potentially promote root development and thus enhance water uptake ${ }^{[16]}$. Crops grown in soils with low water holding capacity (e.g., sand and loamy sand) may not respond to nitrogen applications ${ }^{[20]}$, and this limits the increase in crop water productivity.

Evidence in support of the effects of loamy soils on crop water productivity from a typical long-term experiment shows that clayey soils are more likely to reduce crop water productivity ${ }^{[21]}$. Specifically, the water productivity of multiple crops, namely potato, maize, sunflower, and sugar beet, grown in clay soil declined significantly by $22 \%-25 \%$ compared to crops grown in loam soil ${ }^{[21]}$. The decline in water productivity in maize was primarily attributed to a decrease in yield, while the decline in other crops resulted mainly from the balance between a significant decrease in yield and a significant decrease in evapotranspiration. Although statistically non-significant, an apparent decline in crop water productivity was also detected in soybean and tomato grown in clay soil ${ }^{[21]}$. A coherent explanation for the decline in crop water productivity may be that a deficit of water uptake occurred in the crops grown in clay soil during the peak growing season, and this is supported by observations of stomatal conductance, leaf surface evaporation and daily evapotranspiration ${ }^{[21]}$.

Although most crops grow more in loamy soils, there are crops that are more suitable for clayey or sandy soils. Specifically, the rice grain yield in a clay soil was found to be $46 \%$ higher than that in a sandy loam soil across cultivars and irrigation treatments $^{[22]}$. In a similar fashion to grain yield, the rice water productivity in a clay soil was found to be $25 \%$ higher than in a sandy loam soil ${ }^{[22]}$. These results indicate that rice grows better in clayey soils. In contrast to rice, potato grows better in sandy soils. A previous study shows that potato grown in loamy sand soil produced significantly higher fresh yield than that planted in coarse sand or sandy loam soils, largely due to higher leaf area indexes, higher rates of photosynthesis and a stay-green effect late in the growing season ${ }^{[23]}$. The water productivity of different crops in different soil textures is summarized in Table 1. Generally, a relative high clay content can have a negative effect on water productivity, and loam soils can be more conducive to plant growth. For instance, maize, quinoa, soybean and tomato have a greater water productivity in loam soils, and higher clay or sand contents is less recommended for these crops (Table 1). However, clay or clay loam soils are suitable for rice (Table 1). Loam soils are suitable for wheat. Sandy soils are a better choice for cotton, potato, and sunflower (Table 1). Different irrigation strategies and soil management should therefore be adopted for different crop species on different soil types across multiple environments.

\subsection{Effects of soil bulk density and aggregate size on crop water productivity}

Soil bulk density can significantly affect soil porosity and consequently influence soil water retention, soil moisture infiltration, water transport characteristics and soil hydraulic properties, thus potentially affecting crop yield and water productivity. Soil bulk densities have been found to be closely associated with soil texture and soil organic matter content ${ }^{[29]}$. In general, the bulk density is greater in sandy soils but low in clayey soils. Also, soils with high organic matter contents have low bulk densities ${ }^{[29]}$. These soil types have loose soil textures that benefit crop growth. A pot experiment with different bulk densities $\left(1.4,1.6\right.$, and $\left.1.8 \mathrm{~g} \cdot \mathrm{cm}^{-3}\right)$ showed that maize growth and yield were restricted by high bulk density, and shoot dry weight, leaf area, and shoot apex height were significantly higher under the moderate bulk density of $1.6 \mathrm{~g} \cdot \mathrm{cm}^{-3[30]}$. A moderate soil bulk density can be suitable to increase crop yield and water productivity. Soil bulk density that is either too high or too low reduced crop water productivity ${ }^{[30]}$. When soil bulk density is too high, soil moisture content can decline and mechanical resistance increase $^{[31]}$. Also, high bulk density can influence root elongation rate thus decreasing the total root length. When growing in hard soils, roots will send signals to the plant to reduce the expansion rate and the stomatal conductance of the leaves ${ }^{[13]}$. High bulk density can also decrease soil aeration and the microbial population ${ }^{[32]}$. The numbers of microorganisms and enzyme activities therefore decrease with increasing soil depth. However, when the soil bulk density is too low, it is easier for water to evaporate at the soil surface and to readily percolate into the subsoil, and this can adversely affect crop water productivity $^{[31]}$.

Theoretically, most of the soil physical properties affecting crop 


\begin{tabular}{|c|c|c|c|c|c|}
\hline Crop & Study & Soil texture & Location & Reference & $\mathrm{WP}\left(\mathrm{kg} \cdot \mathrm{m}^{-3}\right)$ \\
\hline \multirow[t]{3}{*}{ Wheat } & 1 & Silt loam & Simulation results & {$[24]$} & 1.21 \\
\hline & & Sandy loam & & & 1.14 \\
\hline & & Loamy sand & & & 1.05 \\
\hline \multirow[t]{2}{*}{ Rice } & 2 & Clay & Beaumont, Texas, USA & {$[22]$} & 0.50 \\
\hline & & Sandy loam & & & 0.40 \\
\hline \multirow[t]{2}{*}{ Maize } & 3 & Clay soil & Murewa, Zimbabwe & {$[25]$} & 1.56 \\
\hline & & Sandy soil & & & 0.80 \\
\hline \multirow[t]{2}{*}{ Maize } & 4 & Clay & Mediterranean region & [21] & 0.87 \\
\hline & & Loam & & & 1.13 \\
\hline \multirow[t]{2}{*}{ Sunflower } & 5 & Clay & Mediterranean region & {$[21]$} & 0.18 \\
\hline & & Loam & & & 0.24 \\
\hline \multirow[t]{4}{*}{ Sunflower } & 6 & Clay loam & Bushland, Texas, USA & [26] & 0.44 \\
\hline & & Silt loam & & & 0.46 \\
\hline & & Sandy loam & & & 0.50 \\
\hline & & Fine sand & & & 0.54 \\
\hline \multirow[t]{3}{*}{ Potato } & 7 & Sandy loam & Foulum, Denmark & {$[23]$} & 20.40 \\
\hline & & Loamy sand & & & 21.40 \\
\hline & & Corase sand & & & 24.00 \\
\hline \multirow[t]{2}{*}{ Potato } & 8 & Clay & Mediterranean region & {$[21]$} & 16.10 \\
\hline & & Loam & & & 21.00 \\
\hline \multirow[t]{2}{*}{ Potato } & 9 & Sandy loam & Ludhiana,India & {$[27]$} & 13.64 \\
\hline & & Loamy sand & & & 12.33 \\
\hline \multirow[t]{3}{*}{ Quinoa } & 10 & Sand & Foulum, Denmark & [28] & 1.29 \\
\hline & & Sandy loam & & & 1.38 \\
\hline & & Sandy clay loam & & & 1.26 \\
\hline \multirow[t]{2}{*}{ Sugar beet } & 11 & Clay & Mediterranean region & {$[21]$} & 6.11 \\
\hline & & Loam & & & 7.85 \\
\hline \multirow[t]{3}{*}{ Cotton (seed) } & 12 & Silt loam & Simulation results & {$[24]$} & 0.29 \\
\hline & & Sandy loam & & & 0.28 \\
\hline & & Loamy sand & & & 0.31 \\
\hline \multirow[t]{2}{*}{ Soybean } & 13 & Clay & Mediterranean region & {$[21]$} & 0.73 \\
\hline & & Loam & & & 0.81 \\
\hline \multirow[t]{2}{*}{ Soybean } & 14 & Loamy sand & Ludhiana, India & [15] & 0.19 \\
\hline & & Sandy loam & & & 0.33 \\
\hline \multirow[t]{2}{*}{ Tomato } & 15 & Clay & Mediterranean region & {$[21]$} & 8.01 \\
\hline & & Loam & & & 8.65 \\
\hline
\end{tabular}

yield can be attributed to soil aggregates ${ }^{[30]}$. Soil aggregate stability is a complex feature influenced by physical, chemical and biological processes in soils. The size of aggregates is an important characteristic that can influence crop growth ${ }^{[13]}$.
Generally, soil aggregates range from $<250$ to $2000 \mu \mathrm{m}$, and are categorized as micro aggregates $(\leqslant 250 \mu \mathrm{m})$ and macro aggregates $(>250 \mu \mathrm{m})^{[33]}$. Crops mostly grow better in soil with small aggregates. For example, maize grew better in pots 
containing the smallest aggregates $(<160 \mu \mathrm{m})$ than in those with larger aggregates ${ }^{[34]}$. Cotton and sunflower grew best in soil with $150 \mu \mathrm{m}$ aggregate size when grown in pots with aggregates ranging from 150 to $1600 \mu \mathrm{m}^{[35]}$. Although root growth is favored by macro pores, moderate soil porosity can help roots take up more water as well as nutrients and induce positive signals to shoots and leaves. Increased crop yields and water productivities occur only when all the parameters (e.g., soil texture, soil organic matter content, and soil aggregate structure) are appropriate for crop growth and the key requirements in soils (i.e., water, fertilizer, gas and heat) are in balance.

\subsection{Effects of soil moisture, temperature and air content on crop water productivity}

Soil moisture is important in regulating crop water productivity since it can markedly affect crop productivity and evapotranspiration. When soil moisture increases, crop water productivity can be enhanced if the increase in crop productivity is larger than that in evapotranspiration. Conversely, crop water productivity can decline. In support of this point, some studies reveal increasing crop water productivity with increasing soil moisture content ${ }^{[36,37]}$. However, some studies report declines in crop water productivity with higher soil moisture content ${ }^{[38,39]}$, and some other studies show bell-shaped responses of crop water productivity to soil moisture content ${ }^{[40]}$ (Table 2).

The effects of soil temperature on crop water productivity were explored under multiple crop management practices such as intercropping and mulching. Intercropping can significantly reduce soil temperatures, increasing soil moisture content and radiation use efficiency and ultimately elevating crop water productivity $^{[41]}$. Mulching is also an important agricultural management practice that affects soil temperature ${ }^{[42]}$ and generally increases crop water productivity ${ }^{[32,42,43]}$. Increased crop water productivity can occur with a reduced soil temperature possibly due to positive effects on soil moisture content $^{[32,42]}$. However, increased crop water productivity can also occur under an increase in soil temperature possibly due to the positive effect of temperature on plant growth ${ }^{[32,43]}$.

Soil air content can affect root respiration and the water and nutrition uptake ability of roots. A higher soil air content can promote crop growth and root extension, enhance the uptake of irrigation water, and indirectly reduce deep soil leakage, ultimately increase crop water productivity ${ }^{[44,45]}$. Conversely, a lower soil air content can inhibit crop growth. In poorly aerated soils, managements such as appropriate irrigation and drainage strategies and deep plowing can be used to increase the air exchange between the soil and the atmosphere. Besides, aerated irrigation can be used to increase the aeration of the soil by adding oxygen to the root zone ${ }^{[46]}$. Table 3 shows the effects of aerated irrigation on the water productivity of different crops. The results indicate that aerated irrigation can increase water productivity in tomatoes by $74.2 \%$, indicating that tomatoes are particularly responsive to an increase in soil oxygen. In addition, cotton was also sensitive to an increase in soil oxygen content because its water productivity increased by $64.6 \%$ with aerated irrigation. In contrast, crops such as pineapple, chickpeas and Japanese green beans did not respond significantly to aeration in the root zone.

\section{LINKAGE BETWEEN CROP WATER PRODUCTIVITY AND SOIL CHEMICAL PROPERTIES}

\subsection{Effects of soil fertility on crop water productivity}

Soil fertility is the ability of soils to provide plant nutrients for crop growth and development ${ }^{[12]}$, and it is linked tightly with crop yield. Soil fertility is also associated with crop water consumption by influencing crop traits such as leaf area index $^{[49]}$. As a result, soil fertility can influence crop water productivity. Currently, the linkage between soil fertility and crop water productivity mainly involves two aspects: relation-

Table 2 Water productivity (WP) of different crops in relation to soil moisture content

\begin{tabular}{lccccc}
\hline \hline Crop & Study & Location & Soil moisture treatment & Reference & WP $\left(\mathrm{kg} \cdot \mathrm{m}^{-3}\right)$ \\
\hline Alfalfa & 1 & Gansu, China & $40 \%-70 \% \theta_{F C}$ & {$[38]$} & {$[40]$} \\
Alfalfa & 2 & Gansu, China & $0 \%-75 \% \theta_{F C}$ & {$[39]$} & $2.01-3.64$ \\
Pearl millet & 3 & Tehran, Iran & $0 \%-60 \% \theta_{A W}$ & {$[37]$} & $2.84-3.44$ \\
Wheat & 4 & Ludhiana, India & $55 \%-85 \% \theta_{F C}$ & {$[36]$} & $4.51-1.71$ \\
Banana & 5 & India & $40 \%-80 \% \theta_{A W}$ & $4.15-10.82$ \\
\hline \hline
\end{tabular}

Note: $\theta_{F C}$, soil water content at field capacity; $\theta_{A W}$, soil water content available between field capacity and wilting point. 
Table 3 Increment in crop water productivity (WP) under aerated irrigation

\begin{tabular}{|c|c|c|c|c|}
\hline Crop & Study & Location & Reference & WP increment (\%) \\
\hline Potato & 1 & Giza, Egypt & [45] & 38.5 \\
\hline Potato & 2 & Giza, Egypt & [45] & 34.8 \\
\hline Maize & 3 & Giza, Egypt & [44] & 35.7 \\
\hline Maize & 4 & Giza, Egypt & [44] & 36.0 \\
\hline Wheat & 5 & Australia & [47] & 16.3 \\
\hline Cotton (Seed) & 6 & Australia & [47] & 64.6 \\
\hline Tomato & 7 & Rockhampton, Australia & [46] & 74.2 \\
\hline Pineapple & 8 & Yeppoon, Australia & [47] & 4.3 \\
\hline Chickpea & 9 & Australia & [48] & 4.3 \\
\hline Edamame & 10 & Australia & [48] & 1.9 \\
\hline Pumpkin & 11 & Australia & [48] & 18.9 \\
\hline
\end{tabular}

ships between original (native) soil fertility and soil fertilization on crop water productivity. The effects of soil fertilization on crop water productivity have received greater interest since fertilizer application is a standard practice in crop production that has led to significant increases in yields. Studies concerning the effects of soil fertilization on crop water productivity can further be classified as: (1) effects of inorganic fertilizers (e.g., nitrogen, phosphorus and potassium), (2) effects of organic fertilizers, and (3) interactions between inorganic and organic fertilizers or manures.

The relationships between basic soil fertility and crop water productivity have been investigated in previous studies. Soil organic carbon, a key indicator in basic soil fertility, generally has a positive effect on crop water productivity ${ }^{[25]}$. Some studies found positive relationships between soil total nitrogen as well as total phosphorus and crop yield ${ }^{[50]}$. In addition to total soil organic matter, the relationship between available nutrients and crop water productivity was also examined in a recent study which analyzed data from 118 sampling sites using the partial least squares method in the arid oasis region of north-west China ${ }^{[10]}$. This study shows that soil nitrate and available phosphorus were key factors driving irrigated crop water productivity across this arid agricultural ecosystem.

Nitrogen is a component of proteins, nucleic acids, phospholipids and other organic nitrogen compounds necessary for plant growth and development. These are the functional components on which living cells depend. Nitrogen is therefore called a living element ${ }^{\text {, } 12]}$ and plays a key role in crop growth and possibly in crop water productivity. Based on nitrogen fertilization experiments, most studies show that appropriate application of nitrogen fertilizers generally increased crop water productivity ${ }^{[51,52]}$. However, if the application was excessive, nitrogen fertilization did not increase crop water productivity and may even have decreased it $^{[39]}$. In addition, nitrogen fertilization that is not excessive may also appear to have an effect on crop water productivity in water-limited environments but this has been found to be non-significant ${ }^{[12]}$. Table 4 presents the water productivity of different crops under different nitrogen application rates and Fig. 1 shows the relationship between nitrogen rate and the water productivity of three crops. Nitrogen application can lead to a wide range of crop water productivities (Table 4 ). The water productivity of potato ranged from 6.7 to $19.5 \mathrm{~kg} \cdot \mathrm{m}^{-3}$. Cereal crops also responded to nitrogen fertilization. For example, the water productivity of maize ranged from 0.33 to $2.23 \mathrm{~kg} \cdot \mathrm{m}^{-3}$ and that of rice from 0.50 to $1.85 \mathrm{~kg} \cdot \mathrm{m}^{-3}$. The water productivity of cotton (seed) ranged from 0.33 to $1.17 \mathrm{~kg} \cdot \mathrm{m}^{-3}$. These crops showed different responses to different nitrogen rates (Table 4 ). For example, the effective nitrogen rate for potato ranged from 0 to $340 \mathrm{~kg} \cdot \mathrm{ha}^{-1} \mathrm{~N}$ (Table 4) and the water productivity of potato increased when the nitrogen rate was within this range but decreased with higher nitrogen rates, fitting a parabolic curve (Fig. 1(a)). Maize (Fig. 1(b)) and rice (Fig. 1(c)) showed similar trends. From the data in our summary, the most appropriate nitrogen rate is about 300 and $200 \mathrm{~kg} \cdot \mathrm{ha}^{-1}$ $\mathrm{N}$, respectively, for maize and rice to obtain the highest water productivity.

Second in importance to nitrogen, phosphorus is another plant macronutrient. Currently, knowledge of the effects of phosphorus fertilization on crop water productivity mostly include the following aspects: (1) phosphorus application can increase crop water productivity ${ }^{[67]},(2)$ phosphorus application at depth 
Table 4 Water productivity (WP) of different crops in relation to nitrogen rate.

\begin{tabular}{|c|c|c|c|c|c|c|}
\hline Crop & Study & $\begin{array}{l}\text { Nitrogen rate } \\
\left(\mathrm{kg} \cdot \mathrm{ha}^{-1} \mathrm{~N}\right)\end{array}$ & Location & Soil property & Reference & $\mathrm{WP}\left(\mathrm{kg} \cdot \mathrm{m}^{-3}\right)$ \\
\hline Potato & 1 & $80-240$ & Palmerston, New Zealand & pH 5.4; soil bulk density $1.35 \mathrm{~g} \cdot \mathrm{cm}^{-3}$ & [53] & $7.0-8.3$ \\
\hline Potato & 2 & $160-340$ & $\begin{array}{l}\text { Nubaria region west of Nile } \\
\text { Delta of Egypt }\end{array}$ & $\begin{array}{l}\text { Sandy in texture, } \mathrm{pH} 8.2 \text {, } \\
\qquad \text { EC } 0.85 \mathrm{dS} \cdot \mathrm{m}^{-1}\end{array}$ & [54] & $9.0-19.5$ \\
\hline Potato & 3 & $0-225$ & Ludhiana, India & Sandy loam soil, EC $0.2 \mathrm{dS} \cdot \mathrm{m}^{-1}$ & [27] & $6.7-15.7$ \\
\hline Potato & 4 & $90-270$ & Gansu, China & Soil bulk density $1.50 \mathrm{~g} \cdot \mathrm{cm}^{-3}$ & [55] & $9.6-12.8$ \\
\hline Maize & 5 & $0-225$ & Lexington, KY, USA & Maury silt loam & [56] & $0.61-1.66$ \\
\hline Maize & 6 & $0-300$ & Vasto, Chieti, Italy & $\begin{array}{c}\text { Clay } 40.7 \% \text {, silt } 52.9 \% \text {, sand } 6.4 \% \text {, soil } \\
\text { bulk denstiy } 1.25 \mathrm{~kg} \cdot \mathrm{dm}^{-3}\end{array}$ & [57] & $1.46-2.23$ \\
\hline Maize & 7 & $0-100$ & Buenos Aires, Argentina & Sandy-loam, Typic Hapludoll & [58] & $0.95-1.48$ \\
\hline Maize & 8 & $0-200$ & Western Uzbekistan & $\begin{array}{l}\text { Sandy loam to loam texture, } \\
\qquad \text { EC } 2-12 \mathrm{dS} \cdot \mathrm{m}^{-1}\end{array}$ & [59] & $0.33-0.95$ \\
\hline Cotton (seed) & 9 & $80-200$ & Pali-Marwar, India & Fine loamy in texture, $1.42 \mathrm{~g} \cdot \mathrm{cm}^{-3}$ & [60] & $0.33-0.46$ \\
\hline Cotton (seed) & 10 & $50-250$ & Northern Syria & Clay soil, Chromoxerertic Rhodoxeralf & [61] & $0.36-0.80$ \\
\hline Cotton (seed) & 11 & $0-240$ & Station near Hama, Syria & l & [62] & $0.50-1.17$ \\
\hline Cotton (raw) & 12 & $0-250$ & Western Uzbekistan & $\begin{array}{l}\text { Sandy loam to loam texture, } \\
\text { EC } 2-12 \mathrm{dS} \cdot \mathrm{m}^{-1}\end{array}$ & [59] & $0.74-0.97$ \\
\hline Cotton (lint) & 13 & $0-240$ & Shandong, China & Sandy loam & [63] & $1.10-1.48$ \\
\hline Wheat & 14 & $0-200$ & Western Uzbekistan & $\begin{array}{l}\text { Sandy loam to loam texture, } \\
\text { EC } 2-12 \mathrm{dS} \cdot \mathrm{m}^{-1}\end{array}$ & [59] & $0.67-2.15$ \\
\hline Rice & 15 & $85-173$ & Lahijan, Iran & - & [64] & $1.16-1.67$ \\
\hline Rice & 16 & $0-180$ & Hubei, China & Silty clay loam & [65] & $0.50-1.48$ \\
\hline Rice & 17 & $0-270$ & Guangdong, China & pH 5.5 & [66] & $0.85-1.85$ \\
\hline
\end{tabular}

Note: EC, electrical conductivity.

is an effective method to increase crop performance including crop water productivity in semiarid regions ${ }^{[68]}$, and (3) the combination of phosphorus fertilization with arbuscular mycorrhizal fungal inoculation is another effective way to increase crop water productivity ${ }^{[69]}$. In addition to nitrogen and phosphorus, potassium is a plant nutrient that is widely applied in agricultural ecosystems and can promote the synthesis of proteins in plants and increase crop drought resistance ${ }^{[70]}$. Similar to nitrogen and phosphorus, potassium fertilization can increase crop water productivity ${ }^{[71]}$.

Nitrogen, phosphorus and potassium are included in most compound fertilizers and are generally applied simultaneously instead of independently. Therefore, attention should be given to the relative proportions of nitrogen, phosphorus and potassium applied, i.e. balanced fertilization. For this reason, studies have focused on the effect of combined use of nitrogen, phosphorus and potassium fertilizer on crop water productivity. By studying maize water productivity across soil fertility domains on smallholdings in Zimbabwe, a study found that balanced fertilizer management had an overriding effect on maize crop productivity in soils with soil organic carbon content $>4 \mathrm{~g} \cdot \mathrm{kg}^{-1[72]}$. Also, this study found that nitrogen and phosphorus fertilizer are still the most limiting nutrients for maize growth, and in contrast potassium fertilization did not increase grain yields nor did it alter the response of crop production to nitrogen or phosphorus fertilization $^{[72]}$.

Many studies also have focused on effects of organic fertilizers, especially the combined use of organic and inorganic fertilizers, on crop water productivity. Understanding these issues involves the following aspects: (1) appropriate organic amendments in addition to the balanced use of organic and inorganic fertilizers can increase crop water productivity ${ }^{[73]}$, (2) the combination of plastic film mulching and organic and inorganic fertilizers can significantly enhance crop water productivity ${ }^{[74]}$, (3) large amounts of inorganic fertilizers combined with organic manures can decrease crop yields, crop water productivity 

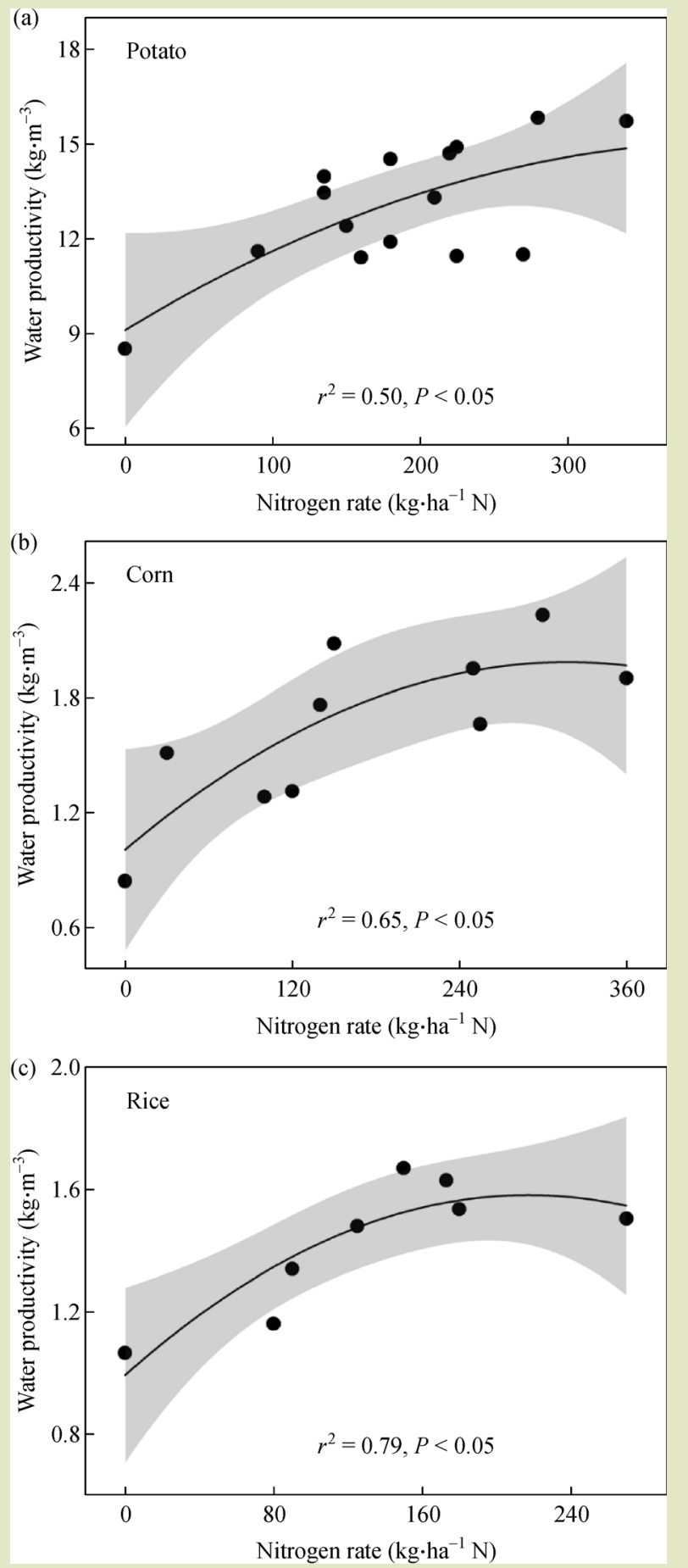

Fig. 1 Relationships between crop water productivity (WP) and nitrogen rates in different crops: (a) potato ${ }^{[27,54,55]}$; (b) maize $\mathrm{i}^{[56-59]}$; (c) rice $\mathrm{e}^{[64,66]}$. Solid lines represent the fitted lines and gray areas denote the $95 \%$ confidence intervals.

and nitrogen use efficiency while increasing the residual nitrate contents in soils ${ }^{[75]}$.

\subsection{Effects of soil pH on crop water productivity}

Soil $\mathrm{pH}$ is a key chemical factor shaping a healthy soil environment for biological activity and is a key variable affecting the forms and availability of nutrients in soils. Soil $\mathrm{pH}$ can influence crop water productivity by regulating soil nutrient availability, microbial activity, plant root nutrition and other biogeochemical processes in soils ${ }^{[76]}$. Currently, knowledge of the effects of soil $\mathrm{pH}$ on crop water productivity are mainly on the following aspects: (1) effects of liming application on crop water productivity ${ }^{[77]}$, and (2) effects of sulfur application on crop water productivity ${ }^{[78]}$.

Each crop species is adapted to an optimum soil $\mathrm{pH}$ range. A soil $\mathrm{pH}$ outside this range, either too acidic or too alkaline, can have negative effects on crop growth and hence crop water productivity ${ }^{[12]}$. Soils in tropical and subtropical regions are generally strongly acid largely due to high rainfall and leaching, and this may depress crop growth and water productivity ${ }^{[79]}$. Studies concerning the effects of lime application on crop growth and water productivity were conducted to increase crop water productivity in these acid soils. These studies generally show that the addition of lime to strongly acid soils may enhance crop water productivity, such as with maize in the subtropical northeastern Himalayas $^{[77]}$, maize/cowpea intercropping in a highly acid tropical soil in Brazil ${ }^{[80]}$ and alfalfa in an acid soil in Australia $^{[81]}$.

A soil is considered to be calcareous when its $\mathrm{pH}$ is $>7.5^{[12]}$. Phosphorus availability is generally low in calcareous soils in which the high soil $\mathrm{pH}$ can induce lower phosphorus availability ${ }^{[12]}$. It has been reported that plants cannot survive in soils with $\mathrm{pH}>10.5$ due to a lack of available phosphorus ${ }^{[78]}$. Soil acidification can be an effective method of ameliorating calcareous soils. Application of sulfur is a widely used method of soil acidification that can alter the physical and chemical properties of calcareous soils so to increase crop yields ${ }^{[82]}$.

\subsection{Effects of soil electrical conductivity on crop water productivity}

Soil electrical conductivity is a measure of the ability of the soil solution to conduct electric current and is widely used to reflect the degree of soil salinity and alkalinity ${ }^{[12]}$. In general, soils with a higher salinity or alkalinity exhibit higher electrical conductivity ${ }^{[12]}$. Saline soils, i.e. soils with excessive soluble salts or exchangeable sodium in the root zone, are widely distributed around the world ${ }^{[83]}$. In addition, salt-affected soils can significantly affect crop growth and water consumption ${ }^{[84]}$. Knowledge of the effects of soil salinity on crop water 
productivity is therefore important in increasing crop productivity globally.

Evidence from grain and industrial crops indicates that soils with larger electrical conductivity generally decrease crop water productivity ${ }^{[85-87]}$. For example, the water productivity of maize declined significantly with the application of saline water ( 4.18 to $9.74 \mathrm{dS} \cdot \mathrm{m}^{-1}$ ) compared to fresh water (1.10 to $2.23 \mathrm{dS} \cdot \mathrm{m}^{-1}$ ) in a saline coastal region of Bangladesh ${ }^{[86]}$. Also, the highest water productivity, irrigation water productivity and yield of cotton occurred in a low salinity soil (17 to $\left.25 \mathrm{mS} \cdot \mathrm{cm}^{-1}\right)$ compared to the medium ( 29 to $50 \mathrm{mS} \cdot \mathrm{cm}^{-1}$ ) and high ( 52 to 62 $\mathrm{mS} \cdot \mathrm{cm}^{-1}$ ) salinity soils in the Tarim River Basin in central Asia $^{[85]}$. A depressed water productivity was found in multiple crops such as snap bean, snow pea, celery and pepper when irrigated with highly saline water ${ }^{[87,88]}$.

Mechanisms involved in the influence of salt stress during crop growth are mainly associated with inhibition of enzyme activity, inhibition of seed germination, restrained growth and differentiation of plant tissues, reduced leaf area and lower rates of photosynthesis. The salinity-induced growth reduction in crops can be biphasic with osmotic stress during the first phase and ion toxicity during the second phase ${ }^{[89]}$. Salt stress during the germination phase can primarily delay the start of germination and disperse germination events by significantly lowering the osmotic potential of the soil to restrict seed water uptake ${ }^{[84]}$. Salinity can also reduce shoot growth by suppressing leaf initiation and expansion ${ }^{[84]}$ and rapidly decrease leaf growth rate $^{[58]}$. Salt stress affects stomatal conductance due to perturbed water relations and then decreases rates of crop transpiration and photosynthesis, consequently leading to reduced crop yields. Both transpiration and net photosynthesis rates were observed to decrease in maize under salt stress ${ }^{[90]}$. Sodium toxicity is the major mechanism in the second phase of salt stress. High sodium concentrations in maize can interfere with the uptake of nitrogen, potassium, calcium, magnesium and iron, causing water loss and leading to disturbance in stomatal function. Nitrogen uptake by shoots and grains have been reported to significantly decline at $6 \mathrm{dS} \cdot \mathrm{m}^{-1}$ salinity in irrigation water $^{[91]}$. Moreover, salt stress can reduce grain weights and numbers in maize, leading to reduce in grain yields and water productivity.

It has been reported that biochar and magnetic treatment of irrigation water can effectively reduce the negative effects induced by saline irrigation water ${ }^{[22]}$. There are two main explanations for this. The first is that biochar can decrease soil osmotic potential and make crops take up more nutrients ${ }^{[93]}$. The second is that biochar has a highly porous structure and large surface area that can significantly enhance the soil water holding capacity and thus help to mitigate the salt induced osmotic stress and ion toxicity to crops ${ }^{[94]}$. Similar to biochar, magnetic treatment of irrigation water can decrease ions in saline water or recycled water and hence decrease osmotic stress effects on crop growth and production ${ }^{[92]}$. The combination of biochar and fertilization can enhance overall soil quality, further increasing crop yield and water productivity in alkaline soils ${ }^{[5]}$. However, adding biochar can also reduce the supply of available water and hence can generate some negative effects on crop water productivity ${ }^{[12]}$.

\section{LINKAGES BETWEEN CROP WATER PRODUCTIVITY AND SOIL MICROBIAL PROPERTIES}

The soil microbial community is a key driver in biogeochemical cycles of agricultural ecosystems ${ }^{[11]}$. Crop water productivity is an indicator of agricultural ecosystem biogeochemical cycling and may also be influenced by the soil microbial community. Most relevant studies have focused on the effects of root microbial inoculation on crop water productivity ${ }^{[67,96,97]}$. In general, root microbial inoculation such as arbuscular mycorrhizal fungal inoculation, rhizobial inoculation and phosphate solubilizing bacterial inoculation, have all been shown to have positive effects on crop water productivity. There are two main explanations. The first is that crops in agricultural ecosystems have prevailing nutrition limitations, especially nitrogen and phosphorus, largely due to removal at harvest ${ }^{[98]}$. The second is that the microorganisms in the inocula, arbuscular mycorrhizal fungi, rhizobium and phosphate solubilizing bacteria, can promote the decomposition of soil organic matter and the availability of nutrients, thus helping crops take up more nutrients for their growth and development ${ }^{[99]}$. The role of arbuscular mycorrhizal fungi has received the greatest attention $^{[67,96,97,99]}$. This may be because: (1) most crops have arbuscular mycorrhizal fungi, (2) arbuscular mycorrhizal fungi can obtain nutrients as well as water effectively for crops, and (3) arbuscular mycorrhizal fungal inoculation has an potentially wide application in agricultural production ${ }^{[96,99]}$.

When analyzing the effects of root microbial inoculation on crop water productivity, some studies have also examined the interactions between root microbial inoculation and other agronomic management practices on crop water productivity $^{[67,96,97,99]}$. Studies have focused on irrigation, plastic film mulching and phosphorus fertilization. Concerning the interaction with irrigation, microbial inoculation is generally effective in alleviating adverse effects of water stress on crop water 
productivity. Furthermore, the combination of microbial inoculation with film mulching can increase crop water productivity ${ }^{[97]}$. Using interactions with phosphorus fertilization, treatments involving microbial inoculation along with phosphorus fertilizer application have been demonstrated to lead to a significantly higher crop water productivity in comparison with non-microbial inoculants ${ }^{[67,69]}$.

In addition to the effects of microbial community inocula on crop water productivity, more attention needs to be given to interactions between the original (native) soil microbial community and crop water productivity. However, knowledge of this aspect remains limited, preventing deeper insights into the effects of soil microbial community on crop water productivity. The continual development of new technologies in microbiology (e.g., metagenomic sequencing and gene probing) will aid the exploration of the relationship between soil microbial community properties and crop water productivity in the future ${ }^{[11]}$.

\section{CONCLUSIONS}

This review summarizes the effects of soil physical, chemical and microbial properties on crop water productivity. In conclusion, physical properties are important in establishing the foundation for crop growth which can influence crop water productivity through effects on soil moisture content, water transfer, soil aeration and soil temperature. Chemical properties affect crop productivity indirectly through the influence of soil structure, nutrient status, soil $\mathrm{pH}$ and reduction-oxidation potential. Regarding microbial properties, the different types of microorganisms in soils affect crop water productivity by promoting the decomposition of soil organic matter and the availability of nutrients. These properties characterize the environment for crop growth that affect crop water productivity independently as well as interactively. In agricultural production systems, suitable combinations of physical and chemical factors can create a healthy environment for microorganisms, which in turn affect the soil physicochemical properties. Further exploration of the influence of soil microbial properties on crop water productivity and the interactions among these three classes of properties (physical, chemical and microbial) on crop water productivity are required. Further studies on the methods for further exploration of the linkages between soil properties and crop water productivity at a regional scale and how to use these linkages in field planning and management are needed. Also, given the potential for separate application of nitrogen through irrigation water (fertigation), its effects on crop water productivity should be examined in the future. Also, taking full consideration of management strategies (e.g. conservation tillage and soil amendments strategies) and climate change is an important way of exploiting the trade-off between soil properties and crop water productivity at field and regional scales.

\footnotetext{
Acknowledgements

This work was partially supported by the National Natural Science Foundation of China (51725904, 51861125103), the Research Projects of Agricultural Public Welfare Industry in China (201503125), and the Discipline Innovative Engineering Plan (111 Program, B14002). Di Wu appreciates the Chinese Scholarship Council for supporting her study at the Department of Soil and Crop Sciences, Colorado State University.
}

\section{Compliance with ethics guidelines}

Di Wu, Allan A. Andales, Hui Yang, Qing Sun, Shichao Chen, Xiuwei Guo, Donghao Li, and Taisheng Du declare that they have no conflicts of interest or financial conflicts to disclose. This article does not contain any studies with human or animal subjects performed by any of the authors.

\section{REFERENCES}

1. Food and Agriculture Organization of the United Nations (FAO). World food and agrigulture-statistical pocketbook 2018. Rome: $I G O, 2018$

2. Morgan J A, Lecain D R, McCaig T N, Quick J S. Gas-exchange, carbon isotope discrimination, and productivity in winterwheat. Crop Science, 1993, 33(1): 178-186

3. Ali M H, Talukder M S U. Increasing water productivity in crop production-a synthesis. Agricultural Water Management,
2008, 95(11): 1201-1213

4. Viets F G. Increasing water use efficiency by soil management. In: Pierre W H, Kirkham D, Pesek J, Shaw R, eds. Plant Environment and Efficiency Water Use. ASA, CSSA, and SSSA Books, 1966, 259-274

5. de Wit C T. Transpiration and crop yields. Wageningen, the Netherlands: Institute of Biology and Chemical Ressarch on Field Crops and Herbage, 1958 
6. Molden D. Accounting for water use and productivity. Colombo, Sri Lanka: International Water Management Institute, 1997

7. Loeve R, Dong B, Molden D, Li Y H, Chen C D, Wang J Z. Issues of scale in water productivity in the Zhanghe irrigation system: implications for irrigation in the basin context. Paddy and Water Environment, 2004, 2(4): 227-236

8. Zwart S J, Bastiaanssen W G M. Review of measured crop water productivity values for irrigated wheat, rice, cotton and maize. Agricultural Water Management, 2004, 69(2): 115-133

9. Chen S C, Wang S F, Shukla M K, Wu D, Guo X W, Li D H, Du $\mathrm{T}$ S. Delineation of management zones and optimization of irrigation scheduling to improve irrigation water productivity and revenue in a farmland of Northwest China. Precision Agriculture, 2020, 21(3): 655-677

10. Li D H, Du T S, Sun Q, Cao Y. The key driving factors of irrigation water productivity based on soil spatio-temporal characteristics. Agricultural Water Management, 2019, 216 : 351-360

11. Crowther T W, van den Hoogen J, Wan J, Mayes M A, Keiser A D, Mo L, Averill C, Maynard D S. The global soil community and its influence on biogeochemistry. Science, 2019, 365(6455): eaav0550

12. Brady N C, Weil R R. The nature and properties of soils. 14th ed. USA: Upper Saddle River, N.J.: Person Prentice Hall, 2008

13. Passioura J B. Soil structure and plant growth. Soil Research, 1991, 29(6): 717-728

14. Fang J, Su Y. Effects of soils and irrigation volume on maize yield, irrigation water productivity, and nitrogen uptake. Scientific Reports, 2019, 9(1): 7740

15. Arora V K, Singh C B, Sidhu A S, Thind S S. Irrigation, tillage and mulching effects on soybean yield and water productivity in relation to soil texture. Agricultural Water Management, 2011, 98(4): 563-568

16. Katerji N, Mastrorilli M, Rana G. Water use efficiency of crops cultivated in the Mediterranean region: review and analysis. European Journal of Agronomy, 2008, 28(4): 493-507

17. Katerji N, Mastrorilli M, Cherni H E. Effects of corn deficit irrigation and soil properties on water use efficiency. A 25-year analysis of a Mediterranean environment using the STICS model. European Journal of Agronomy, 2010, 32(2): 177-185

18. Jalota S K, Singh S, Chahal G B S, Ray S S, Panigraghy S, Bhupinder S, Singh K B. Soil texture, climate and management effects on plant growth, grain yield and water use by rainfed maize-wheat cropping system: field and simulation study. Agricultural Water Management, 2010, 97(1): 83-90

19. Katerji N, van Hoorn J W, Hamdy A, Mastrorilli M, Karzel E M. Osmotic adjustment of sugar beets in response to soil salinity and its influence on stomatal conductance, growth and yield. Agricultural Water Management, 1997, 34(1): 57-69

20. Muschietti-Piana M D P, Cipriotti P A, Urricariet S, Peralta N R, Niborski M. Using site-specific nitrogen management in rainfed corn to reduce the risk of nitrate leaching. Agricultural Water Management, 2018, 199: 61-70
21. Katerji N, Mastrorilli M. The effect of soil texture on the water use efficiency of irrigated crops: results of a multi-year experiment carried out in the Mediterranean region. European Journal of Agronomy, 2009, 30(2): 95-100

22. Dou F, Soriano J, Tabien R E, Chen K. Soil texture and cultivar effects on rice (Oryza sativa L.) grain yield, yield components and water productivity in three water regimes. PLoS One, 2016, 11(3): e0150549

23. Ahmadi S H, Andersen M N, Plauborg F, Poulsen R T, Jensen C R, Sepaskhah A R, Hansen S. Effects of irrigation strategies and soils on field grown potatoes: yield and water productivity. Agricultural Water Management, 2010, 97(11): 1923-1930

24. Jalota S K, Sood A, Chahal G B S, Choudhury B U. Crop water productivity of cotton (Gossypium hirsutum L.)-wheat (Triticum aestivum L.) system as influenced by deficit irrigation, soil texture and precipitation. Agricultural Water Management, 2006, 84(1-2): 137-146

25. Dunjana N, Nyamugafata P, Nyamangara J, Mango N, Gwenzi W. Maize water productivity and its relationship to soil properties under integrated cattle manure and mineral-nitrogen fertilizer in a smallholder cropping system. Agronomy Journal, 2015, 107(6): 2410-2418

26. Tolk J A, Howell T A. Sunflower water productivity in four Great Plains soils. Field Crops Research, 2012, 127: 120-128

27. Arora V K, Nath J C, Singh C B. Analyzing potato response to irrigation and nitrogen regimes in a sub-tropical environment using SUBSTOR-Potato model. Agricultural Water Management, 2013, 124: 69-76

28. Razzaghi F, Plauborg F, Jacobsen S E, Jensen C R, Andersen M $\mathrm{N}$. Effect of nitrogen and water availability of three soil types on yield, radiation use efficiency and evapotranspiration in fieldgrown quinoa. Agricultural Water Management, 2012, 109: 20 29

29. Dam R F, Mehdi B B, Burgess M S E, Madramootoo C A, Mehuys G R, Callum I R. Soil bulk density and crop yield under eleven consecutive years of corn with different tillage and residue practices in a sandy loam soil in central Canada. Soil \& Tillage Research, 2005, 84(1): 41-53

30. De Freitas P L, Zobel R W, Snyder V A. A method for studying the effects of soil aggregate size and density. Soil Science Society of America Journal, 1996, 60(1): 288-290

31. Qi Y C, Wang Y Q, Liu J, Yu X S, Zhou C J. Comparative study on composition of soil aggregates with different land use patterns and several kinds of soil aggregate stability index. Transactions of the Chinese Society of Agricultural Engineering, 2011, 27(1): 340-347 (in Chinese)

32. Sarkar S, Singh S R. Interactive effect of tillage depth and mulch on soil temperature, productivity and water use pattern of rainfed barley (Hordium vulgare L.). Soil \& Tillage Research, 2007, 92(1-2): 79-86

33. Tisdall J M, Oades J M. Organic matter and water-stable aggregates in soils. Journal of Soil Science, 1982, 33(2): 141-163

34. Alexander K G, Miller M H. The effect of soil aggregate size on early growth and shoot-root ratio of maize (Zea mays L.). Plant 
and Soil, 1991, 138(2): 189-194

35. Misra R K, Alston A M, Dexter A R. Root growth and phosphorus uptake in relation to the size and strength of soil aggregates. I. Experimental studies. Soil \& Tillage Research, 1988, 11(2): 103-116

36. Bhattacharyya $\mathrm{R} \mathrm{K}$, Rao V N M. Water requirement, crop coefficient and water-use efficiency of 'Robusta' banana under different soil covers and soil moisture regimes. Scientia Horticulturae, 1985, 25(3): 263-269

37. Dar E A, Brar A S, Singh K B. Water use and productivity of drip irrigated wheat under variable climatic and soil moisture regimes in North-West, India. Agriculture, Ecosystems \& Environment, 2017, 248: 9-19

38. Kou D, Su D, Wu D, Li Y. Effects of Regulated Deficit Irrigation on Water Consumption, Hay Yield and Quality of Alfalfa under Subsurface Drip Irrigation. Transactions of the Chinese Society of Agricultural Engineering, 2014, 30(2): 116-123 (in Chinese)

39. Rostamza M, Chaichi M R, Jahansouz M R, Alimadadi A. Forage quality, water use and nitrogen utilization efficiencies of pearl millet (Pennisetum americanum L.) grown under different soil moisture and nitrogen levels. Agricultural Water Management, 2011, 98(10): 1607-1614

40. Tao X, Su D, Kou D. Effects of different irrigation water amounts under sprinkler irrigation on growth, yield and water use efficiency of alfalfa in Shiyang River Basin. Journal of Irrigation and Drainage, 2015, 34(10): 77-80 (in Chinese)

41. Nyawade S O, Karanja N N, Gachene C K K, Gitari H I, Schultegeldermann E, Parker M L. Intercropping optimizes soil temperature and increases crop water productivity and radiation use efficiency of rainfed potato. American Journal of Potato Research, 2019, 96(5): 457-471

42. Kader M A, Senge M, Mojid M A, Nakamura K. Mulching typeinduced soil moisture and temperature regimes and water use efficiency of soybean under rain-fed condition in central Japan. International Soil Water Conservation Research, 2017, 5(4): 302-308

43. Xie Z K, Wang Y J, Cheng G D, Malhi S S, Vera C L, Guo Z H, Zhang Y B. Particle-size effects on soil temperature, evaporation, water use efficiency and watermelon yield in fields mulched with gravel and sand in semi-arid Loess Plateau of northwest China. Agricultural Water Management, 2010, 97(6): 917-923

44. Abuarab M, Mostafa E, Ibrahim M. Effect of air injection under subsurface drip irrigation on yield and water use efficiency of corn in a sandy clay loam soil. Journal of Advanced Research, 2013, 4(6): 493-499

45. Abuarab M E, El-Mogy M M, Hassan A M, Abdeldaym E A, Abdelkader N H, El-Sawy M B I. The effects of root aeration and different soil conditioners on the nutritional values, yield, and water productivity of potato in clay loam soil. Agronomy, 2019, 9 (8): 418

46. Bhattarai S P, Pendergast L, Midmore D J. Root aeration improves yield and water use efficiency of tomato in heavy clay and saline soils. Scientia Horticulturae, 2006, 108(3): 278288
47. Chen X M, Dhungel J, Bhattarai S P, Torabi M, Pendergast L, Midmore D J. Impact of oxygation on soil respiration, yield and water use efficiency of three crop species. Journal of Plant Ecology, 2011, 4(4): 236-248

48. Bhattarai S P, Midmore D J, Pendergast L. Yield, water-use efficiencies and root distribution of soybean, chickpea and pumpkin under different subsurface drip irrigation depths and oxygation treatments in vertisols. Irrigation Science, 2008, 26(5): 439-450

49. Cooper P J M, Gregory P J, Keatinge J D H, Brown S C. Effects of fertilizer, variety and location on barley production under rainfed conditions in Northern Syria 2. Soil water dynamics and crop water use. Field Crops Research, 1987, 16(1): 67-84

50. Liu Z J, Zhou W, Shen J B, He P, Lei Q L, Liang G Q. A simple assessment on spatial variability of rice yield and selected soil chemical properties of paddy fields in South China. Geoderma, 2014, 235-236: 39-47

51. AlKhader A M F, Qaryouti M M, Okasheh T Y M. Effect of nitrogen on yield, quality, and irrigation water use efficiency of drip fertigated grafted watermelon (Citrullus lanatus) grown on a calcareous soil. Journal of Plant Nutrition, 2019, 42(7): 737748

52. Kumar A, Sharma D K, Sharma H C. Growth, yield and wateruse efficiency of wheat (Triticum aestivum) as influenced by irrigation and nitrogen in sodic soils. Indian Journal of Agronomy, 1994, 39(2): 220-224

53. Fandika I R, Kemp P D, Miliner J P, Horne D, Roskruge N. Irrigation and nitrogen effects on tuber yield and water use efficiency of heritage and modern potato cultivars. Agricultural Water Management, 2016, 170: 148-157

54. Badr M A, El-Tohamy W A, Zaghloul A M. Yield and water use efficiency of potato grown under different irrigation and nitrogen levels in an arid region. Agricultural Water Management, 2012, 110: 9-15

55. Yang K J, Wang F X, Shock C C, Kang S Z, Huo Z L, Song N, Ma D. Potato performance as influenced by the proportion of wetted soil volume and nitrogen under drip irrigation with plastic mulch. Agricultural Water Management, 2017, 179: 260-270

56. Corak S J, Frye W W, Smith M S. Legume mulch and nitrogenfertilizer effects on soil-water and corn production. Soil Science Society of America Journal, 1991, 55(5): 1395-1400

57. Di Paolo E, Rinaldi M. Yield response of corn to irrigation and nitrogen fertilization in a Mediterranean environment. Field Crops Research, 2008, 105(3): 202-210

58. Diaz-Zorita M. Effect of deep-tillage and nitrogen fertilization interactions on dryland corn (Zea mays L.) productivity. Soil \& Tillage Research, 2000, 54(1-2): 11-19

59. Devkota M, Martius C, Lamers J P A, Sayre K D, Devkota K P, Gupta R K, Egamberdiev O, Vlek P L G. Combining permanent beds and residue retention with nitrogen fertilization improves crop yields and water productivity in irrigated arid lands under cotton, wheat and maize. Field Crops Research, 2013, 149: 105114

60. Dzotsi K A, Jones J W, Adiku S G K, Naab J B, Singh U, Porter C 
H, Gijsman A J. Modeling soil and plant phosphorus within DSSAT. Ecological Modelling, 2010, 221(23): 2839-2849

61. Janat M. Response of cotton to irrigation methods and nitrogen fertilization: yield components, water-use efficiency, nitrogen uptake, and recovery. Communications in Soil Science and Plant Analysis, 2008, 39(15-16): 2282-2302

62. Janat M, Somi G. Performance of cotton crop grown under surface irrigation and drip fertigation. II. Field water-use efficiency and dry matter distribution. Communications in Soil Science and Plant Analysis, 2001, 32(19-20): 3063-3076

63. Dong H Z, Kong X Q, Li W J, Tang W, Zhang D M. Effects of plant density and nitrogen and potassium fertilization on cotton yield and uptake of major nutrients in two fields with varying fertility. Field Crops Research, 2010, 119(1): 106-113

64. Ashouri M. Water use efficiency, irrigation management and nitrogen utilization in rice production in the North of Iran. APCBEE Procedia, 2014, 8: 70-74

65. Belder P, Bouman B A M, Cabangon R, Lu G A, Quilang E J P, Li Y H, Spiertz J H J, Tuong T P. Effect of water-saving irrigation on rice yield and water use in typical lowland conditions in Asia. Agricultural Water Management, 2004, 65(3): 193-210

66. Pan J F, Liu Y Z, Zhong X H, Lampayan R M, Singleton G R, Huang N R, Liang K M, Peng B L, Tian K. Grain yield, water productivity and nitrogen use efficiency of rice under different water management and fertilizer-N inputs in South China. Agricultural Water Management, 2017, 184: 191-200

67. Yadav A, Suri V K, Kumar A, Choudhary A K, Meena A L. Enhancing plant water relations, quality, and productivity of pea (Pisum sativum L.) through arbuscular mycorrhizal fungi, inorganic phosphorus, and irrigation regimes in an himalayan acid alfisol. Communications in Soil Science and Plant Analysis, 2015, 46(1): 80-93

68. Kang L Y, Yue S C, Li S Q. Effects of phosphorus application in different soil layers on root growth, yield, and water-use efficiency of winter wheat grown under semi-arid conditions. Journal of Integrative Agriculture, 2014, 13(9): 2028-2039

69. Farahani A, Lebaschi H, Hussein M, Hussein S A, Reza V A, Jahanfar D. Effects of arbuscular mycorrhizal fungi, different levels of phosphorus and drought stress on water use efficiency, relative water content and proline accumulation rate of coriander (Coriandrum sativum L.). Journal of Medicinal Plants Research, 2008, 2(6): 125-131

70. Perrenoud S. Potassium and plant health. Bern-Worblaufen, Switzerland: International Potash Institute, 1977, 218

71. Liu J, Hu T, Feng P, Wang L, Yang S. Tomato yield and water use efficiency change with various soil moisture and potassium levels during different growth stages. PLoS One, 2019, 14(3): e0213643

72. Kurwakumire N, Chikowo R, Mtambanengwe F, Mapfumo P, Snapp S, Johnston A, Zingore S. Maize productivity and nutrient and water use efficiencies across soil fertility domains on smallholder farms in Zimbabwe. Field Crops Research, 2014, 164: $136-147$

73. Amoah A A, Senge M, Miyagawa S, Itou K. Effects of soil fertility management on growth, yield, and water-use efficiency of maize (Zea mays L.) and selected soil properties. Communications in Soil Science and Plant Analysis, 2012, 43(6): 924-935

74. Liang Z E. Effects of different cropping patterns and fertilization on soil fertility, the yield of potato and water use efficiency. Journal of Irrigation and Drainage, 2016, 35(1): 53-58 (in Chinese)

75. Yu X, Zhai B, Jin Z, Li Y, Wang Y, Zhang H, Wang Z. Effect of combined application of organic and inorganic fertilizers on winter wheat yield,water and fertilizer use efficiency and soil fertility in dryland. Journal of Soil and Water Conservation, 2015, 29(5): 320-324 (in Chinese)

76. Timsina J, Connor D J. Productivity and management of ricewheat cropping systems: issues and challenges. Field Crops Research, 2001, 69(2): 93-132

77. Marwein M A, Choudhury B U, Chakraborty D, Kumar M, Das A, Rajkhowa D J. Response of water deficit regime and soil amelioration on evapotranspiration loss and water use efficiency of maize (Zea mays L.) in subtropical northeastern Himalayas. International Journal of Biometeorology, 2017, 61(5): 845-855

78. Lin S L. Effects of sulfur fertilizer and $\mathrm{pH}$ on available phosphorus and grain yield. Dissertation for the Doctoral Degree. Lanzhou: Lanzhou University, 2011 (in Chinese)

79. Chapin F S, Matson P A, Mooney H A. Principles of terrestrial ecosystem ecology. New York: Springer, 2011, 369-397

80. Gaiser T, de Barros I, Lange F M, Williams J R. Water use efficiency of a maize/cowpea intercrop on a highly acidic tropical soil as affected by liming and fertilizer application. Plant and Soil, 2004, 263(1): 165-171

81. Hayes R C, Li G D, Conyers M K, Virgona J M, Dear B S. Lime increases productivity and the capacity of lucerne (Medicago sativa L.) and phalaris (Phalaris aquatica L.) to utilise stored soil water on an acidic soil in south-eastern Australia. Plant and Soil, 2016, 400(1-2): 29-43

82. Germida J J, Janzen $\mathrm{H}$ H. Factors affecting the oxidation of elemental sulfur in soils. Fertilizer Research, 1993, 35(1-2): 101114

83. Rengasamy P. Soil processes affecting crop production in saltaffected soils. Functional Plant Biology, 2010, 37(7): 613-620

84. Farooq M, Hussain M, Wakeel A, Siddique K H M. Salt stress in maize: effects, resistance mechanisms, and management. A review. Agronomy for Sustainable Development, 2015, 35(2): 461-481

85. Yang J Y, Mei X R, Huo Z G, Yan C R, Hui J, Zhao F H, Qin L. Water consumption in summer maize and winter wheat cropping system based on SEBAL model in Huang-Huai-Hai Plain, China. Journal of Integrative Agriculture, 2015, 14(10): 2065-2076

86. Ibn Murad K F, Hossain A, Faki O A, Biswas S K, Sarker K K, Rannu R P, Timsina J. Conjunctive use of saline and fresh water increases the productivity of maize in saline coastal region of Bangladesh. Agricultural Water Management, 2018, 204: 262270

87. Grewal H S, Maheshwari B L. Treated effeluent and saline water 
irrigation influences soil properties, yield, water productivity and sodium content of snow peas and celery. Journal of Plant Nutrition, 2013, 36(7): 1102-1119

88. Rameshwaran P, Tepe A, Yazar A, Ragab R. Effects of dripirrigation regimes with saline water on pepper productivity and soil salinity under greenhouse conditions. Scientia Horticulturae, 2016, 199: 114-123

89. Munns R. Physiological processes limiting plant growth in saline soils - some dogmas and hypotheses. Plant, Cell \& Environment, 1993, 16(1): 15-24

90. Gong X L, Chao L, Zhou M, Hong M M, Luo L Y, Wang L, Ying W, Cai J W, Gong S J, Hong F S. Oxidative damages of maize seedlings caused by exposure to a combination of potassium deficiency and salt stress. Plant and Soil, 2011, 340(1-2): 443452

91. Gadalla A, Hamdy A, Galal Y, Aziz H, Mohamed M. Evaluation of maize grown under salinity stress and $\mathrm{N}$ application strategies using stable nitrogen isotope. In: 8th African Crop Science Society Conference. El-Minia, Egypt: African Crop Science Society, 2007, 1653-1662

92. Maheshwari B L, Grewal H S. Magnetic treatment of irrigation water: its effects on vegetable crop yield and water productivity. Agricultural Water Management, 2009, 96(8): 1229-1236

93. Rezaie N, Razzaghi F, Sepaskhah A R. Different levels of irrigation water salinity and biochar influence on faba bean yield, water productivity, and ions uptake. Communications in
Soil Science and Plant Analysis, 2019, 50(5): 611-626

94. Akhtar S S, Andersen M N, Liu F L. Residual effects of biochar on improving growth, physiology and yield of wheat under salt stress. Agricultural Water Management, 2015, 158: 61-68

95. Zhang X, Qu J S, Li H, La S K, Tian Y Q, Gao L H. Biochar addition combined with daily fertigation improves overall soil quality and enhances water-fertilizer productivity of cucumber in alkaline soils of a semi-arid region. Geoderma, 2020, 363: 114170

96. Pirzad A, Mohammadzadeh S. Water use efficiency of three mycorrhizal Lamiaceae species (Lavandula officinalis, Rosmarinus officinalis and Thymus vulgaris). Agricultural Water Management, 2018, 204: 1-10

97. Bi Y L, Qiu L, Zhakypbek Y, Jiang B, Cai Y, Sun H. Combination of plastic film mulching and AMF inoculation promotes maize growth, yield and water use efficiency in the semiarid region of Northwest China. Agricultural Water Management, 2018, 201: 278-286

98. LeBauer D S, Treseder K K. Nitrogen limitation of net primary productivity in terrestrial ecosystems is globally distributed. Ecology, 2008, 89(2): 371-379

99. Gholamhoseini M, Ghalavand A, Dolatabadian A, Jamshidi E, Khodaei-Joghan A. Effects of arbuscular mycorrhizal inoculation on growth, yield, nutrient uptake and irrigation water productivity of sunflowers grown under drought stress. Agricultural Water Management, 2013, 117: 106-114 